\title{
Aqueous plant extracts in the control of Bidens pilosa $\mathrm{L}$.
}

\section{Extratos aquosos vegetais no controle de Bidens pilosa $L$.}

\author{
Jamile da Silva Oliveira1* (D), Clovis Pereira Peixoto² (D, Carlos Alberto da Silva Ledo ${ }^{3}$, \\ Ademir Trindade Almeida ${ }^{2}$
}

\begin{abstract}
Secondary compounds have allelopathic action on germination and growth, and initial development of seedlings and beggar tick can have its germination and growth affected by the action of allelopathic extracts. Thus, this work aimed to evaluate the allelopathic potential of Brachiaria (Brachiaria brizantha), sunflower (Helianthus annuus) and sorghum extracts (Sorghum bicolor) on germination and initial growth of beggar ticks (Bidens pilosa). For this, an experiment was conducted in a completely randomized design with four treatments and six replicates and brachiaria, sunflower and sorghum extracts and control (distilled water) treatments. Extracts were obtained using $200 \mathrm{~g}$ of plant material and $1,000 \mathrm{~mL}$ of distilled water. Seeds were distributed in gerbox containing two sheets of germitest paper moistened with treatments and taken to germination chamber. Germination was daily monitored, and ten days after, initial growth was evaluated. Extracts did not reduce germination. However, they caused increase in germination time, mainly by brachiaria extract. Seedlings submitted to brachiaria and sorghum extracts showed lower growth. Brachiaria and sorghum extracts showed no action on germination, but controlled the initial growth of beggar tick, being potential natural herbicides.
\end{abstract}

KEYWORDS: invasive plants; allelopathy; alternative control.
RESUMO: Compostos secundários têm ação alelopática sobre a germinação, crescimento e desenvolvimento inicial de plântulas, e a Bidens pilosa pode ter sua germinação e crescimento afetados pela ação dos extratos alelopáticos. Nesse sentido, objetivou-se avaliar o potencial alelopático de extratos de braquiária (Brachiaria brizantha), girassol (Helianthus annus) e sorgo (Sorghum bicolor) na germinabilidade e no crescimento inicial de picão-preto (Bidens pilosa). Para isso foi instalado um experimento no delineamento inteiramente casualizado, com quatro tratamentos e seis repetiçóes, sendo eles extrato de braquiária, girassol, sorgo e o controle (água destilada). Os extratos foram obtidos utilizando $200 \mathrm{~g}$ de material vegetal fresco para $1.000 \mathrm{~mL}$ de água destilada. As sementes foram distribuídas em caixa gerbox contendo duas folhas de papel germitest umedecidas com os tratamentos e levadas para a câmara de germinação. Foi acompanhada diariamente a germinação e, após 10 dias, foi avaliado o crescimento inicial. Os extratos não causaram prejuízos à germinação, porém, provocaram demora em seu tempo de eclosáo, sendo o extrato de braquiária o mais prejudicial. As plântulas submetidas aos extratos de braquiária e sorgo apresentaram menor crescimento. Os extratos de braquiária e sorgo náo apresentaram ação sobre a porcentagem de germinação das sementes de picão-preto, mas controlaram o crescimento inicial das plântulas e podem ser indicados para possíveis herbicidas naturais.

PALAVRAS-CHAVE: plantas invasoras; alelopatia; controle alternativo.

\footnotetext{
'Universidade de Brasília - Brasília (DF), Brazil

${ }^{2}$ Universidade Federal do Recôncavo da Bahia - Cruz das Almas (BA), Brazil

${ }^{3}$ Centro Nacional de Pesquisa de Mandioca e Fruticultura Tropical, Empresa Brasileira de Pesquisa Agropecuária -

Cruz das Almas (BA), Brazil

*Corresponding author: jamile.oliveira54@gmail.com

Received on: 07/14/2016. Accepted on: 10/25/2017
} 


\section{INTRODUCTION}

Weed control can be obtained through allelopathy, being an inexpensive method in comparison to others, not pollutant and, most importantly, it does not require the use of sophisticated equipment for its application (OLIVEIRA, 2014). Studies using alternative weed control techniques in cultivated or non-cultivated systems, especially through allelopathy, will become more important the greater the economic and ecological limitations of conventional control practices are (CARVALHO et al., 2012).

Allelopathy can be a very important tool to aid in the verification of benefits or losses in a crop system, in consortium or in succession type, studying the relationships between cultivated species (FERREIRA; AQÜILA, 2000). It is a research area that proposes the use of plant substances, allowing searching for new substances with herbicidal action. These substances with allelopathic activity can be used in the formulation of natural or even altered herbicides in order to improve their biological activity, such as interference in seed germination processes, seedling growth and development (DOUSSEAU et al., 2008).

In the management of cultivated species, infestation with weeds has been a major problem, because weeds compete with the crop of interest causing production losses. Thus, studies have sought to control some weed species using allelopathy (MAULI et al., 2009). With the knowledge of the allelopathic potential of species of agricultural interest, it is easier to choose plant species to compose cultivated systems and to better manage weed control.

Thus, the aim of this study was to evaluate the allelopathic potential of brachiaria, sunflower and sorghum aqueous extracts on the germination and initial growth of beggar tick (Bidens pilosa).

\section{MATERIALS AND METHODS}

The experiment was carried out at the Laboratory of Plant Physiology, Department of Agrarian, Environmental and Biological Sciences of Federal University of Recôncavo da Bahia (UFRB), municipality of Cruz das Almas (Bahia), with coordinates $12^{\circ} 49^{\prime} 19^{\prime \prime} \mathrm{S}$ and $39^{\circ} 06^{\prime} 22^{\prime \prime} \mathrm{W}$, and 220 masl.

A completely randomized experiment was carried out with four treatments: aqueous extract of brachiaria, sunflower and sorghum shoots, with control (distilled water), with six replicates, totaling 24 experimental plots. Each experimental plot consisted of six seeds per gerbox.

Beggar tick (Bidens pilosa L.) seeds were obtained in the experimental field of UFRB; sunflower (Helianthus annuus L.) were from Hélio 250 (black grain) simple hybrid; Brachiaria (Brachiaria brizantha cv. Marandu) and sorghum (Sorghum bicolor L.) were purchased in the local trade, except sunflower, which was donated by Heliagro company.

There was a previous stage for multiplication of brachiaria, sunflower and sorghum plants in greenhouse, for the preparation of the aqueous extract of shoots. In greenhouse, seeds were sown in pots of $5.0 \mathrm{~kg}$ capacity in a mixture of soil, sand and organic fertilizer in a 1:1:1 ratio.

The aqueous extracts of donor species were obtained as it follows: $200 \mathrm{~g}$ of fresh leaves of each species were crushed and mixed with $1,000 \mathrm{~mL}$ of distilled water, adapted from CORSATO et al. (2010). Extracts were filtered and collected in a Becker, and the $\mathrm{pH}$ was determined using $\mathrm{pH}$ meter (Digimed model DM 22). Reading was the average of six replicates.

Six beggar tick seeds were placed to germinate on two sheets of germitest paper moistened with the extracts in the proportion of three times the weight of the dry paper and control with distilled water in gerbox placed in biochemical oxygen demand (BOD)-type germinador Model EL 222, with constant temperature of $25^{\circ} \mathrm{C}$, with 11 hours of light.

Irrigation with distilled water was applied throughout the experimental period to maintain moisture in gerboxes, whenever necessary.

Germination was monitored daily, considering as germination criterion the emission of $2 \mathrm{~mm}$ radicle to obtain the number of germinated seeds of the target species (beggar tick) (FERREIRA; AQÜILA, 2000). The average germination time (TMG) (RANAL; SANTANA, 2006) and the germination speed index (GSI) were determined by recording the number of germinated seeds per day (MAGUIRE, 1962). Seven days after sowing, shoot length (CPA), root system length (CSR) and total dry mass (MMST) were evaluated. From these data, the percentage of shoot and root system inhibition was determined (CHUNG et al., 2001). The normality of seedlings was also evaluated (BRASIL, 2009).

Data were submitted to analysis of variance, and the means of treatments were compared by the Tukey test at $5 \%$ of significance. Statistical analyses were performed by the Assistat-Statistical Attendance software (SILVA; AZEVEDO, 2009). With the aid of the Statistical Analysis System (SAS) software, data normality test was performed by the Shapiro-Wilk test at $5 \%$ significance, in order to observe the distribution of variables. As variables followed normal distribution, with $p>0.05$, Pearson's correlation was performed among variables, except for the germination percentage, which was excluded from the analysis (SAS INSTITUTE, 2004). For percentage data, angular transformation was performed, sine arc $\sqrt{x}_{\mathrm{x}} / 100$; and count data were transformed by $\sqrt{x}_{\mathrm{x}}$. 


\section{RESULTS}

By measuring the $\mathrm{pH}$ of extracts, it could be inferred that none of changes observed in variables can be attributed to $\mathrm{pH}$, since they were found in the ideal $\mathrm{pH}$ range for seed germination (5.5 to 7.0). The $\mathrm{pH}$ values of brachiaria, sunflower and sorghum extracts were 5.62; 6.50; and 6.01, respectively. Therefore, alterations in variables can be attributed to the allelopathic effects of extracts, since the $\mathrm{pH}$ measured is at levels that do not affect germination.

There was no significant interaction for variables germination percentage and GSI. It was verified that the other variables were significant by the $\mathrm{F}$ test of the analysis of variance, which confirms the effect of treatments on the variables analyzed (Table 1). In general, there was increase in coefficient of variation $(\mathrm{CV})$, but all treatments had germination percentage above $60 \%$ (Table 2).

For the averages of variables germination percentage and GSI, there was no difference by the Tukey test.

Brachiaria, sunflower and sorghum extracts increased the mean germination time of beggar tick seeds in relation to the control treatment. However, they did not differ from each other (Table 2).

For variable shoot length (CPA), significant difference was observed. For CSR and formation of normal seedlings, significant difference was observed by the Tukey test (Table 3).

Brachiaria extract caused greater reduction in the shoot length of beggar tick. However, it did not differ from sunflower and sorghum extracts, which did not differ from control with distilled water. It was also observed that brachiaria and sorghum extracts did not differ from each other and were those that affected the CSR and also the formation of normal seedlings in relation to sunflower extract, which did not differ from control.

The sorghum extract reduced the dry matter mass of beggar tick, being the most efficient extract in the reduction of this variable. Changes reflected in plant growth and development, which were pointed out in the present study.
Regarding the inhibition of shoot and root system, all extracts used cause inhibition, and brachiaria and sorghum extracts were more aggressive for both variables (Fig. 1).

Table 2. Means of germination, mean germination time germination speed index of Bidens pilosa $\mathrm{L}$. submitted to treatments with extracts, Cruz das Almas, BA, 2013.

\begin{tabular}{lccc} 
Treatments & G (\%) & TMG (days) & GSI \\
\hline Control & $1.22 \mathrm{a}$ & $2.47 \mathrm{~b}$ & $0.91 \mathrm{a}$ \\
\hline $\begin{array}{l}\text { Brachiaria } \\
\text { extract }\end{array}$ & $1.15 \mathrm{a}$ & $2.83 \mathrm{a}$ & $0.69 \mathrm{a}$ \\
\hline $\begin{array}{l}\text { Sunflower } \\
\text { extract }\end{array}$ & $1.06 \mathrm{a}$ & $2.61 \mathrm{ab}$ & $0.73 \mathrm{a}$ \\
\hline $\begin{array}{l}\text { Sorghum } \\
\text { extract }\end{array}$ & $1.41 \mathrm{a}$ & $2.56 \mathrm{ab}$ & $0.93 \mathrm{a}$ \\
\hline CV (\%) & 30.11 & 7.64 & 24.63 \\
\hline
\end{tabular}

Means followed by the same letter do not differ statistically from each other, by the Tukey test at $5 \%$ probability. $G(\%)$ : germination percentage; TMG: average germination time (days); GSI: germination speed index (germinated seedlings day-1); CV: coefficient of variation.

Table 3. Mean shoot, root system length and percentage of normal seedlings of Bidens pilosa $\mathrm{L}$. submitted to treatments with extracts, Cruz das Almas, BA, 2013.

\begin{tabular}{|c|c|c|c|c|}
\hline Treatments & CPA $(\mathrm{cm})$ & $\operatorname{CSR}(\mathrm{cm})$ & MST (g) & PN (\%) \\
\hline Control & $3.18 \mathrm{a}$ & $4.15 \mathrm{a}$ & $0.024 a$ & $9.85 a$ \\
\hline $\begin{array}{l}\text { Brachiaria } \\
\text { extract }\end{array}$ & $1.78 b$ & $1.75 b c$ & $0.027 a$ & $6.49 \mathrm{~b}$ \\
\hline $\begin{array}{l}\text { Sunflower } \\
\text { extract }\end{array}$ & $2.47 a b$ & $3.09 a b$ & $0.022 \mathrm{a}$ & $7.27 a b$ \\
\hline $\begin{array}{l}\text { Sorghum } \\
\text { extract }\end{array}$ & $2.44 a b$ & $1.61 \mathrm{c}$ & $0.005 b$ & $6.33 \mathrm{~b}$ \\
\hline CV (\%) & 30.00 & 32.71 & 38.53 & 31.37 \\
\hline
\end{tabular}

Averages followed by the same letter do not differ statistically from each other, by the Tukey test at 5\% probability. CPA: shoot length $(\mathrm{cm})$; CSR: root system length (cm); MST: mass of the total dry matter; $\mathrm{PN}$ : percentage of normal seedlings; CV: coefficient of variation.

Table 1. Analysis of variance summary for variables germination percentage, average germination time, germination speed index, shoot length, root system length, total dry matter and percentage of normal seedlings of Bidens pilosa L. submitted to treatments with extracts, Cruz das Almas, BA, 2013.

\begin{tabular}{lcccccccc} 
FV & GL & G (\%) & TMG & GSI & CPA & CSR & MST & PN (\%) \\
Treatments & 3 & $0.13^{\text {ns }}$ & $0.15^{*}$ & $0.09^{\text {ns }}$ & $1.97^{*}$ & $8.66^{* *}$ & $0.00^{* *}$ & $0.71^{* *}$ \\
\hline Residue & 20 & 0.13 & 0.04 & 0.04 & 0.55 & 0.75 & 0.00 & 0.17 \\
\hline MG & & 1.21 & 2.62 & 0.82 & 2.47 & 2.65 & 0.02 & 1.00 \\
\hline CV (\%) & & 30.11 & 7.64 & 24.63 & 30.00 & 32.71 & 38.53 & 41.90 \\
\hline
\end{tabular}

G (\%): germination percentage; TMG: average germination time (days); GSI: germination speed index (germinated seedlings day-1); CPA: shoot length $(\mathrm{cm})$; CSR: root system length ( $\mathrm{cm}$ ); MST: total dry matter (g); PN: percentage of normal seedlings; FV: source of variation; MG: general mean; CV (\%):

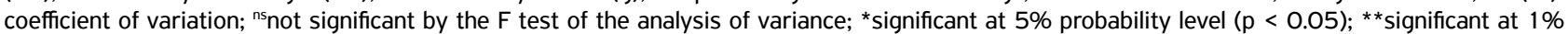
probability level $(p<0.01)$. 
The Shapiro-Wilk normality test at $5 \%$ of significance was not significant for all variables analyzed, indicating that all variables follow normal distribution. Correlations were highly significant by the Student's $t$ test for variables shoot length and CSR and also for the formation of normal seedlings (Table 4).

There was a positive and significant linear correlation at $5 \%$ by the Student's $t$ test for CSR and formation of normal seedlings. This indicates that the formation of a well-developed root system may also result in increased emergence of normal seedlings, and the opposite is also true. For variables GSI and mass of the total dry matter, negative and significant linear correlation was observed.

\section{DISCUSSION}

The changes observed in variables analyzed can be attributed to the allelopathic effects of extracts, because $\mathrm{pH}$ was found at levels that did not affect germination. Since beggar tick is a wild species, without any type of improvement, non-uniform germination was observed (CORSATO et al., 2010), which probably influenced CV.

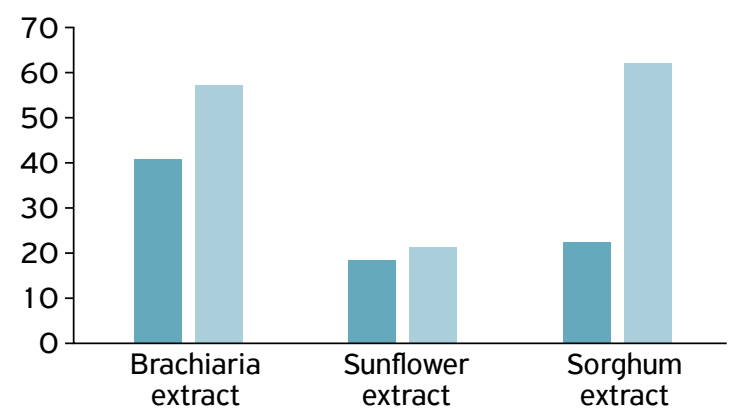

Percentage of shoot (PA) Root system inhibition (SR)

Figure 1. Percentage of shoot and root system inhibition of Bidens pilosa L. submitted to treatments with allelopathic extract, Cruz das Almas, BA, 2013.
Possibly, no differences were verified in the seed germination process because, after the physiological maturation period, seeds require only moisture and oxygen to germinate, which makes this stage the most insensitive to allelochemicals present in the medium (FERREIRA; AQÜILA, 2000). In addition, due to the characteristics of the plant cell membrane and wall, in which allelochemicals can be retained, they function as a semipermeable barrier (TAIZ; ZEIGER, 2013). Using concentration of 200 g.L.' $\mathrm{L}^{-1}$ CORSATO et al. (2010) found reduction in the germination of beggar tick submitted to sunflower aqueous extract. This may be due to differences between each sunflower genotype. However, in the same study, when comparing several sunflower genotypes, not all had the potential to reduce the germination percentage of beggar tick equally, and these changes were attributed to flavonoids (water-soluble substances) present in sunflower plants. In the present study, reduction in the germination percentage could not have been observed, because a hybrid was used to obtain the sunflower extract, which is genetically modified, and may present lower allelopathic potential (KRUSE et al., 2000).

The germination process is less sensitive to allelochemicals, because it is a discrete phenomenon, that is, the seed germinates or not, so the effect can often be observed on another parameter of the germination process, as, in this case, on the mean germination time (FERREIRA; AQÜILA, 2000). In field condition, this is of fundamental importance, since the species of interest would have more time to germinate free from weed interference. This phenomenon could lead to a certain population of weeds losing dominance to another species, so it may be very advantageous if a weed loses dominance to a cultivated plant (SILVA et al., 2011).

Allelopathy reveals its inhibitory effects, mostly on the formation of the root system (FERREIRA; AQÜILA, 2000). The growth of the root system is very important to guarantee the development and establishment of plants, and, when the root system is affected, it can compromise the entire life cycle, since it depends on an adequate development, including growth and good architecture of the root system for its fixation to the soil and mainly for absorption of water and nutrients, which are essential processes for plant survival.

Table 4. Pearson's linear correlation matrix among evaluated variables, constructed with the aid of the Statistical Analysis System software, Cruz das Almas, BA, 2013.

\begin{tabular}{lccccc} 
Variables & GSI & CPA & CSR & MST & PN \\
\hline TMG & $-0.46^{\text {ns }}$ & $-0.42^{\text {ns }}$ & $-0.39^{\text {ns }}$ & $0.39^{\text {ns }}$ & $-0.31^{\text {ns }}$ \\
\hline IVG & & $0.69^{*}$ & 0.29 ns & $-0.68^{*}$ & $0.46^{\text {ns }}$ \\
\hline CPA & & $0.77^{* *}$ & $-0.37^{\text {ns }}$ & $0.72^{* *}$ \\
\hline CSR & & & $0.06^{\text {ns }}$ & $0.68^{*}$ \\
\hline MMST & & & & $-0.08^{\text {ns }}$
\end{tabular}

${ }^{n}$ not significant by the Student's $t$ test; *significant at $5 \%$; * significant at $1 \%$.

TMG: average germination time (days); GSI: germination speed index (germinated seedlings day-1); CPA: shoot length (cm); CSR: root system length (cm); MMST: mass of the total dry matter; PN: percentage of normal seedlings. 
The literature points out that the allelopathic effects may be more pronounced on roots, which is due to their more intimate contact with the allelochemical solution (FERREIRA; AQÜILA, 2000; CHUNG et al., 2001).

The growth and initial development of seedlings are the stages most affected by the allelopathic substances, and in the present study, changes were observed that literature reports as secondary responses to the primary effects that undergo changes in the plant metabolism (PEDROL et al., 2006; RANAL; SANTANA, 2006).

The changes observed in seedlings may be due to allelopathic substances, that result in effects on membrane permeability, deoxyribonucleic acid (DNA) transcription and translation, secondary messengers functioning, respiration, oxygen sequestration, change in enzyme conformation, or combination of all these factors (FERREIRA, 2004).

The reduction in the growth of beggar tick root observed in the present study was similar to the inhibition occurred in soybean plants submitted to aqueous sorghum extracts (CORREIA et al., 2005).

\section{CONCLUSION}

Brachiaria, sunflower and sorghum extracts did not affect the beggar tick germination, but brachiaria and sorghum extracts were efficient in controlling the initial growth of beggar tick.

\section{ACKNOWLEDGEMENTS}

The authors would like to thank Coordenação de Aperfeiçoamento de Pessoal de Nível Superior - Brazil (CAPES) for partial financial support received - Finance Code 001.

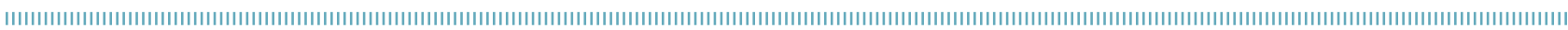
REFERENCES

BRASIL. Ministério da Agricultura, Pecuária e Abastecimento. Regras para análise de sementes. 1. ed. Brasília: Mapa/ACS, 2009. 399p.

CARVALHO, W.P.; CARVALHO, G.J.; ANDRADE, M.J.B.; FONSECA, G.F.; ANDRADE, L.; VALACI, F.; OLIVEIRA, D.P. Alelopatia de adubos verdes sobre feijoeiro comum (Phaseolus vulgaris L.). Revista Brasileira de Biociências, Porto Alegre, v.10, n. 1, p.8693, 2012.

CORREIA, N.M.; CENTURION, M.A.P.C.; ALVES, P.L.C.A. Influência de extratos aquosos de sorgo sobre a germinação e o desenvolvimento de plântulas de soja. Ciência Rural, Santa Maria, v.35, n.3, p.498-503, 2005. http://dx.doi.org/10.1590/ so $103-84782005000300002$

CORSATO, J.M; FORTES, A.M.T.; SANTORUM, M.; LESZCZYNSKI, R. Efeito alelopático do extrato aquoso de folhas de girassol sobre a germinação de soja e picão-preto. Semina: Ciências Agrárias, Londrina, v.31, n.2, p.353-360, 2010. http://dx.doi. org/10.5433/1679-0359.2010v3 1n2p353

CHUNG, I.M.; AHN, J.K.; YUN, S.J. Assessment of allelopathic potential of barnyard grass (Echinochloa crus-galli) on rice (Oryza sativa L.) cultivars. Crop Protection, Guildfort, v.20, n.10, p.921-928, 2001. https://doi.org/10.1016/ S0261-2194(01)00046-1

DOUSSEAU, S.; ALVARENGA, A.A.; ARANTES, L.O.; OLIVEIRA, D.M.; NERY, F.C. Germinação de sementes de Tanchagem (Plantago tomentosa Lam.): influência da temperatura, luz e substrato. Ciência e Agrotecnologia, Lavras, v.32, n.6, p.438-443,
2008. http://dx.doi.org/10.1590/S1413-70542008000 200014

FERREIRA, A.G.; AQÜILA, M.E.A. Alelopatia: uma área emergente da ecofisiologia. Revista Brasileira de Fisiologia Vegetal, Campinas, v.12, n.esp., p.175-204, 2000.

FERREIRA, A.G. Interferência: competição e alelopatia. In: BORGHETTI, F. (Eds.). Germinação do básico ao aplicado. Porto Alegre: Artmed. 2004, p.251-262.

KRUSE, M.; STRANDBERG, M.; STRANDBERG, B. Ecological effects of allelopathic plants: a review. 1.ed. Silkebor, Denmark: National Environmental Research Institute, 2000. 66p.

MAGUIRE, J.D. Speed of germination aid in selection and evaluation for emergence and vigour. Crop Science, Madson, v.2, n.2, p. 176177, 1962. http://dx.doi.org/10.2135/cropsci 1962.00111 83x000200020033x

MAULI, M.M.; FORTES, A.M.T.; ROSA, D.M.; PICCOLO, G.; MARQUES, D.S.; CORSATO, J.M.; LESZCZYNSKI, R. Alelopatia de Leucena sobre soja e plantas invasoras. Semina: Ciências Agrárias, Londrina, v.30 n. 1, p.55-62, 2009.

OLIVEIRA, J.S. Potencial alelopático em girassol e em braquiária. 2014. 85f. Dissertation (Mestrado em Recursos Genéticos Vegetais) - Universidade Federal do Recôncavo da Bahia, Cruz das Almas, Bahia, 2014.

PEDROL, N.; GONZÁLEZ, L.; REIGOSA, M.J. Allelopathy and abiotic stress. In: REIGOSA, M.J.; PEDROL, N.; GONZÁLEZ, L. (Eds.). 
Allelopathy: a physiological process with ecological implications. Dordrecht: Springer, Holanda, 2006. p.171-209.

RANAL, M.A.; SANTANA, D.G. How and why to measure the germination process? Revista Brasileira de Botânica, São Paulo, v.29, n.1, p.1-11, 2006. http://dx.doi.org/10.1590/S0100-84042006000100002

SAS INSTITUTE Inc. Statistical Analysis System user's Guide. Version 9.1.3. Cary, NC: Statistical Analysis System Institute, 2004. $846 \mathrm{p}$.

SILVA, F.A.S.; AZEVEDO, C.A.V. Principal components analysis in the software Assistat-Statistical Attendance. In: WORLD
CONGRESS ON COMPUTERS IN AGRICULTURE, 7., 2009, Orlando. Proceedings... Reno, NV: American Society of Agricultural and Biological Engineers, 2009. p.393-396.

SILVA, H.L.; TREZZI, M.M.; BUZZELLO, G.; PATEL, F.; MIOTTO JUNIOR, E.; DEBASTIANI, F. Potencial supressivo de genótipos e níveis de palha de girassol (Helianthus annuus L.) sobre o desenvolvimento de picão preto (Bidens pilosa). Revista Brasileira de Agrociência, Pelotas, v.17, n.1-4, p.07-14, 2011 . http:// dx.doi.org/10.18539/cast.v17i1.2026

TAIZ, L.; ZEIGER, E. Fisiologia vegetal. 5. ed. Porto Alegre: Artmed, 2013. 918p. 